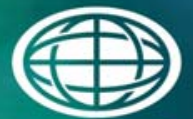

Savannah River

National Laboratory "m

OPERATED BY SAVANNAH RIVER NUCLEAR SOLUTIONS

\title{
Tank 40 Final Sludge Batch 8 Chemical Characterization Results
}

Christopher J. Bannochie, Ph.D.

September 2013

SRNL-STI-2013-00504 
SRNL-STI-2013-00504

Revision 0

\section{DISCLAIMER}

This work was prepared under an agreement with and funded by the U.S. Government. Neither the U.S. Government or its employees, nor any of its contractors, subcontractors or their employees, makes any express or implied:

1. warranty or assumes any legal liability for the accuracy, completeness, or for the use or results of such use of any information, product, or process disclosed; or

2. representation that such use or results of such use would not infringe privately owned rights; or

3. endorsement or recommendation of any specifically identified commercial product, process, or service.

Any views and opinions of authors expressed in this work do not necessarily state or reflect those of the United States Government, or its contractors, or subcontractors.

\section{Printed in the United States of America \\ Prepared for U.S. Department of Energy}


Keywords: Tank 50, Waste Acceptance Criteria, Saltstone

Retention: Permanent

\section{Tank 40 Final Sludge Batch 8 Chemical Characterization Results}

C. J. Bannochie

September 2013

Prepared for the U.S. Department of Energy under contract number DE-AC09-08SR22470. 


\section{REVIEWS AND APPROVALS}

AUTHOR:

C. J. Bannochie, Process Technology Programs

Date

TECHNICAL REVIEW:

\begin{tabular}{ll}
\hline J. M. Pareizs, Process Technology Programs, Reviewed per E7, $2.60 \quad$ Date
\end{tabular}

APPROVAL:

D. R. Click, Manager, Process Technology Programs

Date

S. L. Marra, Manager, E\&CPT Research Programs

Date

E. J. Freed, Manager, DWPF Facility Engineering

Date 


\section{ACKNOWLEDGEMENTS}

The author would like to thank the Shielded Cells Operations (SCO) technicians for their attention and promptness in handling all of the samples generated by this activity. Dr. Chris Martino for receipt and intial processing of HTF-40-13-119. In addition, the assistance of Dr. Chuck Coleman (Analytical Development) in preparing the aqua regia and alkali fusion digestions is recognized. DWPF sludge batch data was supplied by Roger Mahannah (Savannah River Remediation, LLC). 


\section{EXECUTIVE SUMMARY}

A sample of Sludge Batch 8 (SB8) was pulled from Tank 40 in order to obtain radionuclide inventory analyses necessary for compliance with the Waste Acceptance Product Specifications (WAPS) ${ }^{1}$. The SB8 WAPS sample was also analyzed for chemical composition, including noble metals, and fissile constituents, and these results are reported here. These analyses along with the WAPS radionuclide analyses will help define the composition of the sludge in Tank 40 that is currently being fed to the Defense Waste Processing Facility (DWPF) as SB8.

At SRNL, the 3-L Tank 40 SB8 sample was transferred from the shipping container into a 4-L high density polyethylene bottle and solids were allowed to settle. Supernate was then siphoned off and circulated through the shipping container to complete the transfer of the sample. Following thorough mixing of the 3-L sample, a $553 \mathrm{~g}$ sub-sample was removed. This sub-sample was then utilized for all subsequent slurry sample preparations.

Eight separate aliquots of the slurry were digested, four with $\mathrm{HNO}_{3} / \mathrm{HCl}$ (aqua regia ${ }^{\mathrm{i}}$ ) in sealed Teflon ${ }^{\circledR}$ vessels and four with $\mathrm{NaOH} / \mathrm{Na}_{2} \mathrm{O}_{2}$ (alkali or peroxide fusion ${ }^{\mathrm{ii}}$ ) using $\mathrm{Zr}$ crucibles. Two Analytical Reference Glass - $1^{\text {iii }}$ (ARG-1) standards were digested along with a blank for each preparation. Each aqua regia digestion and blank was diluted to $1: 100 \mathrm{~mL}$ with deionized water and submitted to Analytical Development (AD) for inductively coupled plasma - atomic emission spectroscopy (ICP-AES) analysis, inductively coupled plasma - mass spectrometry (ICP-MS) analysis, atomic absorption spectroscopy (AA) for As and $\mathrm{Se}$, and cold vapor atomic absorption spectroscopy (CV-AA) for $\mathrm{Hg}$. Equivalent dilutions of the alkali fusion digestions and blank were submitted to AD for ICP-AES analysis.

Tank 40 SB8 supernate was collected from a mixed slurry sample in the SRNL Shielded Cells and submitted to AD for ICP-AES, ion chromatography (IC), total base/free $\mathrm{OH}^{\%} /$ other base, total inorganic carbon/total organic carbon (TIC/TOC) analyses. Weighted dilutions of slurry were submitted for IC, $\mathrm{TIC} / \mathrm{TOC}$, and total base/free $\mathrm{OH}^{-} /$other base analyses.

Activities for U-233, U-235, and Pu-239 were determined from the ICP-MS data for the aqua regia digestions of the Tank 40 WAPS slurry using the specific activity of each isotope. The Pu-241 value was determined from a Pu-238/-241 method developed by SRNL AD and previously described. ${ }^{\text {iv }}$

The following conclusions were drawn from the analytical results reported here:

\footnotetext{
${ }^{\mathrm{i}}$ Coleman, C. J. Aqua Regia Dissolution of Sludge for Elemental Analysis, Manual L16.1, Procedure ADS-2226, Rev. 9, Savannah River Site, Aiken, SC 29808 (2009).

${ }^{i i}$ Coleman, C. J. Alkali Fusion Dissolutions of Sludge and Glass for Elemental and Anion Analysis, Manual L16.1, ADS-2502, Rev. 6, Savannah River Site, Aiken, SC 29808 (2008).

iii Smith, G. L. Characterization of Analytical Reference Glass - 1 (ARG-1), PNL-8992, Pacific Northwest (National) Laboratory, Richland, WA (1993).

${ }^{\text {iv }}$ Bannochie, C. J., DiPrete, D. P. Determination of Reportable Radionuclides for DWPF Sludge Batch 6 (Macrobatch 7), SRNL-STI-2011-000189, Savannah River Site, Aiken, SC 29808 (2011).
} 
- The ratios of the major elements for the SB8 WAPS sample are different from those measured for the SB7b WAPS sample. There is less $\mathrm{Al}$ and $\mathrm{U}$, and more Mn relative to Fe than the previous sludge batch.

- The elemental composition of this sample and the analyses conducted here are reasonable and consistent with DWPF batch data measurements in light of DWPF pre-sample concentration, SRAT product heel contributions, and PRFT additions to the DWPF SRAT receipt sample. The element ratios for $\mathrm{Al} / \mathrm{Fe}, \mathrm{Ca} / \mathrm{Fe}, \mathrm{Mn} / \mathrm{Fe}$, and $\mathrm{U} / \mathrm{Fe}$ agree within $5 \%$ between this work and the DWPF SRAT receipt analyses.

- Sulfur in the SB8 WAPS sample is $86 \%$ soluble, slightly less than results reported for SB3, SB4, and SB6 samples but unlike the 50\% insoluble sulfur observed in the SB5 WAPS sample. In addition, $21 \%$ of the soluble sulfur is not present as sulfate in SB8.

- The average activities of the fissile isotopes of interest in the SB8 WAPS sample are (in $\mu \mathrm{Ci} / \mathrm{g}$ of total dried solids): 6.52E-02 U-233, 5.20E-04 U-235, 7.78E+00 Pu-239, and 4.32E+01 Pu-241. The full radionuclide composition will be reported in a future document.

- The fission product noble metal and Ag concentrations appear to have largely peaked in previous DWPF sludge batches. The concentration of Ru has decreased significantly in SB8. 


\section{TABLE OF CONTENTS}

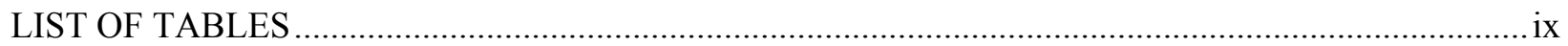

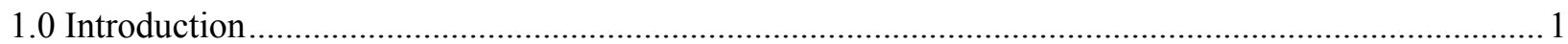

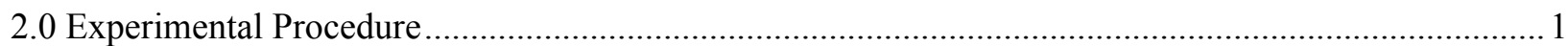

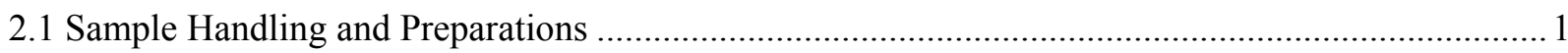

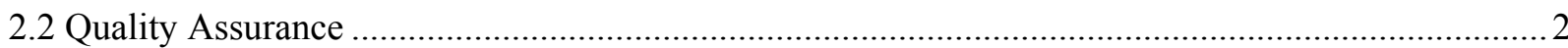

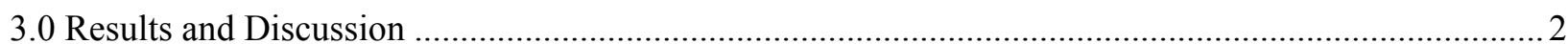

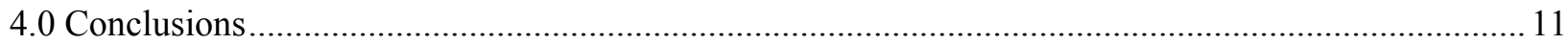

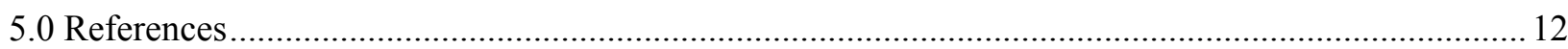

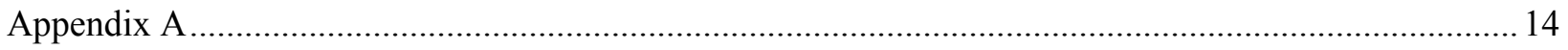


SRNL-STI-2013-00504

Revision 0

\section{LIST OF TABLES}

Table 3-1. Weight Percent Solids and Density for Tank 40 SB8 WAPS Samples, Tank Farm Projections, and DWPF SRAT Receipt Batch 676 [Number of Samples Included in Average]............................. 3

Table 3-2. Supernate Analyses for Tank 40 SB8 WAPS Samples and DWPF SRAT Receipt Batch 676 [Number of Samples Included in Average] ................................................................................ 4

Table 3-3. Carbon Analysis for Tank 40 SB8 WAPS Samples and DWPF SRAT Receipt Batch 676 [Number of Samples Included in Average] (mg C/kg slurry) ..........................................................5

Table 3-4. Base Analysis for Tank 40 SB8 WAPS Samples and DWPF SRAT Receipt Batch 676 [Number of Samples Included in Average] (mol/kg slurry) ............................................................ 6

Table 3-5. Elemental Concentrations* in Tank 40 SB8 WAPS Samples in Wt. \% of Total Dried Solids $\left(\% \mathrm{RSD}^{* *}\right)$ [Number of Samples Included in Average] ................................................................. 7

Table 3-6. Comparison of Elemental Ratios for Major Insoluble Elements in the Tank 40 SB4, SB5, SB6, SB7a, SB7b, and SB8 Samples with DWPF Batch 676 SRAT Receipt Data .................................... 8

Table 3-7. Replicate Concentrations of Iron for the Tank 40 SB8 WAPS Sample in Wt.\% of Total Dried Solids

Table 3-8. Replicate Activities of Fissile Radionuclides for the Tank 40 SB8 WAPS Sample in $\mu$ Ci/g of Total Dried Solids*

Table 3-9. Replicate Weight Percent Solids and Densities for Tank 40 SB8 WAPS Sample 9

Table 3-10. Noble Metal Fission Product and Silver Concentrations in Tank 40 SB4, SB5, SB6, SB7a, SB7b, and SB8 WAPS Samples in Wt. \% of Total Solids (\%RSD)

Table 3-11. Fission Yield Ratios and Measured Noble Metal Ratios in SB4, SB5, SB6, SB7a, SB7b, and SB8 WAPS Samples.

Table A-1. ICP-AES Results for Elements Reported Based on ICP-MS Data in Table 3-5 for Tank 40 SB8 WAPS Samples in Wt.\% of Total Dried Solids (\%RSD**) [Number of Samples Included in Average]

\section{LIST OF FIGURES}

Figure 3-1. Noble Metal Fission Product and Silver Concentrations (Wt. \% of Total Solids) in Tank 40 WAPS Samples for SB4 through SB8. 


\section{LIST OF ABBREVIATIONS}

\begin{tabular}{|c|c|}
\hline $\mathrm{AD}$ & Analytical Development \\
\hline $\mathrm{AF}$ & Alkali Fusion \\
\hline $\mathrm{ARG}-1$ & Analytical Reference Glass - 1 \\
\hline ASP & Analytical Study Plan \\
\hline $\mathrm{CC}$ & Cold Chemistry (Digestion) \\
\hline CV-AA & Cold Vapor - Atomic Absorption Spectroscopy \\
\hline DWPF & Defense Waste Processing Facility \\
\hline HLW & High Level Waste \\
\hline $\mathrm{IC}$ & Ion Chromatography \\
\hline ICP-AES & Inductively Coupled Plasma - Atomic Emission Spectroscopy \\
\hline ICP-MS & Inductively Coupled Plasma - Mass Spectrometry \\
\hline $\mathrm{L}$ & Liter \\
\hline$\mu \mathrm{Ci}$ & Microcuries \\
\hline M & Molar \\
\hline NA & Not Available (e.g. Not Measured) \\
\hline PRFT & Precipitate Reactor Feed Tank \\
\hline RSD & Relative Standard Deviation \\
\hline SB3 & Sludge Batch 3 \\
\hline SB4 & Sludge Batch 4 \\
\hline SB5 & Sludge Batch 5 \\
\hline SB6 & Sludge Batch 6 \\
\hline SB7a & Sludge Batch 7a \\
\hline SB7b & Sludge Batch $7 \mathrm{~b}$ \\
\hline SB8 & Sludge Batch 8 \\
\hline SRAT & Sludge Receipt and Adjustment Tank \\
\hline SRNL & Savannah River National Laboratory \\
\hline Std. Dev. & Standard Deviation \\
\hline TC & Total Carbon \\
\hline TIC & Total Inorganic Carbon \\
\hline TOC & Total Organic Carbon \\
\hline $\mathrm{TS}$ & Total Dried Solids \\
\hline TTQAP & Task Technical and Quality Assurance Plan \\
\hline TTR & Technical Task Request \\
\hline
\end{tabular}


SRNL-STI-2013-00504

Revision 0

WAPS Waste Acceptance Product Specifications

Wt.\% Weight Percent 


\subsection{Introduction}

A sample of Sludge Batch 8 (SB8) was pulled from Tank 40 in order to obtain radionuclide inventory analyses necessary for compliance with the Waste Acceptance Product Specifications (WAPS) ${ }^{1}$. The SB8 WAPS sample was also analyzed for chemical composition, including noble metals, and fissile constituents, and these results are reported here. These analyses along with the WAPS radionuclide analyses will help define the composition of the sludge in Tank 40 that is currently being fed to the Defense Waste Processing Facility (DWPF) as SB8.

Savannah River National Laboratory (SRNL) analyses on SB8 were requested by DWPF via Technical Task Request (TTR) HLW-DWPF-TTR-2012-0009, Rev. 2. ${ }^{2}$ The sample preparation work is governed by a Task Technical and Quality Assurance Plan (TTQAP) ${ }^{3}$, and analyses were controlled by an Analytical Study Plan ${ }^{4}$.

A 3-L sample of Tank 40 (HTF-40-13-117) was pulled and delivered to the SRNL Shielded Cells on July 9,2013 following slurry operations. This sample was initially designated as the WAPS sample by DWPF. Four slurry pumps were operated for nine to 11 hours preceding sample collection, and the sample was collected not more than one hour after discontinuing slurry operations. The general protocol is for all four slurry pumps to run for eight hours before a DWPF transfer and to be kept running during the transfer, but due to the need to pull a sample, the pumps had to be shut down. The tank level was 208.4 inches after the pumps were secured and when the sample was pulled. A second 3-L sample of Tank 40 (HTF-40-13-119) was pulled and delivered on July 10, 2013 following slurry operations. The initial intent of this second sample was to support SB8 Processability Studies. ${ }^{5}$ Initial examination of the wt.\% solids for HTF-40-13-117 indicated values significantly higher than anticipated based upon Tank Farm Projections. ${ }^{6}$ A comparison of the HTF-40-13-117 and HTF-40-13-119 samples has been issued previously. ${ }^{7}$ A decision was made by DWPF to assign the sample HTF-40-13-119 as the WAPS sample for the purposes of this report and the subsequent report on the radionuclide decay projections.

\subsection{Experimental Procedure}

\subsection{Sample Handling and Preparations}

At SRNL, the 3-L Tank 40 SB8 sample was transferred from the shipping container into a 4-L high density polyethylene bottle and solids were allowed to settle. Supernate was then siphoned off and circulated through the shipping container to complete the transfer of the sample. Following thorough mixing of the 3-L sample, a $553 \mathrm{~g}$ sub-sample was removed. This sub-sample was then utilized for all subsequent slurry sample preparations.

Eight separate aliquots of the slurry were digested, four with $\mathrm{HNO}_{3} / \mathrm{HCl}$ (aqua regia ${ }^{8}$ ) in sealed Teflon ${ }^{\circledR}$ vessels and four with $\mathrm{NaOH} / \mathrm{Na}_{2} \mathrm{O}_{2}$ (alkali or peroxide fusion ${ }^{9}$ ) using $\mathrm{Zr}$ crucibles. Due to the use of $\mathrm{Zr}$ crucibles and $\mathrm{Na}$ in the peroxide fusions, $\mathrm{Na}$ and $\mathrm{Zr}$ cannot be determined from this preparation. Additionally, other alkali metals, such as Li and $\mathrm{K}$ that may be contaminants in the $\mathrm{NaOH} / \mathrm{Na}_{2} \mathrm{O}_{2}$ are not determined from this preparation. Two Analytical Reference Glass $-1^{10}$ (ARG-1) standards were digested along with a blank for each preparation. The ARG-1 glass allows for an assessment of the completeness of each digestion. A multielement metal ion standard was submitted with each digestion, 
and the elemental checks were within $\pm 10 \%$ of the expected value. Each aqua regia digestion and blank was diluted to $1: 100 \mathrm{~mL}$ with deionized water and submitted to Analytical Development (AD) for inductively coupled plasma - atomic emission spectroscopy (ICP-AES) analysis, inductively coupled plasma - mass spectrometry (ICP-MS) analysis of masses 82-208 and 230-244, atomic absorption spectroscopy (AA) for As and Se, and cold vapor atomic absorption spectroscopy (CV-AA) analysis for $\mathrm{Hg}$. Equivalent dilutions of the alkali fusion digestions and a blank were submitted to AD for ICP-AES analysis.

Tank 40 SB8 supernate was collected from a mixed slurry sample in the SRNL Shielded Cells and submitted to AD for ICP-AES, ion chromatography (IC), total inorganic carbon/total organic carbon (TIC/TOC), and total base/free $\mathrm{OH}^{-}$other base analyses. Weighted dilutions of slurry were submitted for IC, TIC/TOC, and total base/free $\mathrm{OH}^{-} /$other base analyses.

Activities for U-233, U-235, and Pu-239 were determined from the ICP-MS data for the aqua regia digestions of the Tank 40 WAPS slurry using the specific activity of each isotope. The Pu-241 value was determined from a Pu-238/-241 method developed by SRNL AD and previously described. ${ }^{11}$

\subsection{Quality Assurance}

Requirements for performing reviews of technical reports and the extent of review are established in manual E7 2.60. SRNL documents the extent and type of review using the SRNL Technical Report Design Checklist contained in WSRC-IM-2002-00011, Rev. 2.

\subsection{Results and Discussion}

Table 3-1 presents the measured SB8 density and weight percent solids data ${ }^{12,13}$ collected for the SB8 WAPS sample taken in July 2013. Table 3-1 also contains data from the DWPF Sludge Receipt and Adjustment Tank (SRAT) receipt sample data for Batch \#676 as a comparison. Batch \#676 was selected because it was the DWPF batch received from Tank 40 just prior to the pulling of HTF-40-13-119. The wt.\% total solids for the Tank 40 - WAPS sample is higher than that seen for Batch \#676, but lower than DWPF measured for Batches \#675 and \#677. Generally, it would be expected to be lower than the total solids observed for the DWPF SRAT receipt batch due to the impacts of the SRAT heel and DWPF presample concentration following Tank 40 and Precipitate Reactor Feed Tank (PRFT) transfers. The SRAT heel contributes approximately $13-19 \%$ of the volume of slurry in the SRAT vessel and can have total solids in the range of $20 \mathrm{wt}$. \%. Calcine factors were also calculated by taking the ratio of the weight percent calcined solids and the weight percent total solids. The Tank 40 - WAPS Sample has a value of 0.76 grams of calcined solids per gram of dried solids. 
Table 3-1. Weight Percent Solids and Density for Tank 40 SB8 WAPS Samples, Tank Farm Projections, and DWPF SRAT Receipt Batch 676 [Number of Samples Included in Average]

\begin{tabular}{|c|c|c|c|}
\hline Property & $\begin{array}{c}\text { Tank } 40 \text { - WAPS } \\
\text { (\% RSD*) }\end{array}$ & $\begin{array}{l}\text { Tank Farm } \\
\text { Projection }^{14}\end{array}$ & $\begin{array}{c}\text { DWPF SRAT } \\
\text { Receipt for Batch } \\
676\end{array}$ \\
\hline $\begin{array}{c}\text { Slurry Density } \\
(\mathrm{g} / \mathrm{mL})\end{array}$ & $1.16(1.0)[4]$ & 1.13 & 1.12 \\
\hline $\begin{array}{c}\text { Supernate Density } \\
\qquad(\mathrm{g} / \mathrm{mL})\end{array}$ & $1.06(0.2)[4]$ & 1.06 & NA \\
\hline $\begin{array}{c}\text { Total Solids (Wt.\% } \\
\text { in Slurry) }\end{array}$ & $17.21(0.9)[8]$ & 17.52 & 16.98 \\
\hline $\begin{array}{l}\text { Calcined Solids } \\
\text { (Wt.\% in Slurry) }\end{array}$ & $13.13(0.8)[4]$ & 13.41 & NA \\
\hline $\begin{array}{l}\text { Dissolved Solids } \\
\text { (Wt.\% in Supernate) }\end{array}$ & $6.64(1.1)[4]$ & NA & NA \\
\hline $\begin{array}{l}\text { Insoluble Solids } \\
\text { (Wt.\% in Slurry) }\end{array}$ & 11.32 & 11.68 & NA \\
\hline $\begin{array}{l}\text { Soluble Solids }{ }^{\mathrm{b}} \text { (Wt.\% } \\
\text { in Slurry) }\end{array}$ & 5.89 & NA & NA \\
\hline \multicolumn{4}{|c|}{$\begin{array}{l}\mathrm{NA} \equiv \text { not measured } \\
\text { Parenthetical \%RSD values are relative to the true calculated averages of the quantities in the table, while the average values reported } \\
\text { have been rounded off to a reasonable number of significant figures. } \\
\text { Also known as Uncorrected Soluble Solids }\end{array}$} \\
\hline
\end{tabular}

Table 3-2 provides the anion results for the Tank 40 WAPS sample and the available DWPF SRAT receipt data for Batch \#676. In order to compare the data from the two labs it was necessary to put the SRNL data on a slurry basis. SRNL data in Columns 2 and 3 of the table are presented on a supernate basis, i.e. moles/L of supernate, but were the result of weighted dilutions of slurry and weighted dilutions of supernate, respectively. Columns 4 and 5 in the table are presented on a slurry basis, i.e. $\mathrm{mg} / \mathrm{kg}$ slurry, but were the result of weighted dilutions of slurry and weighted dilutions of supernate, respectively. As a result, Columns 2 and 4 are from the same set of weighted dilutions, and Columns 3 and 5 are from a separate set of weighted dilutions.

The supernate sulfur result is calculated from total sulfur detected in the supernate by ICP-AES and is about $21 \%$ higher, on a molar basis, than sulfate sulfur determined by IC, this is consistent with the approximately $23 \%$ difference seen for SB $7 b{ }^{15}$ This difference between total soluble sulfur and sulfate soluble sulfur was observed throughout SB6 washing ${ }^{16}$ and it appears to be true again for SB8. As was shown, this non-sulfate, soluble sulfur does not appear to persist following SRAT cycle processing. ${ }^{17}$ The Al, B, Ca, Cr, Fe, K, Mo, Na, S, and $\mathrm{Sr}$ values also shown in this table were calculated from the ICP-AES data for the supernate and placed on a slurry basis using the insoluble solids content from Table 3-1. Other supernate elements measured were below the ICP-AES detection limits or present at equivalent levels in the blank. 
Table 3-2. Supernate Analyses for Tank 40 SB8 WAPS Samples and DWPF SRAT Receipt Batch 676 [Number of Samples Included in Average]

\begin{tabular}{|c|c|c|c|c|c|c|}
\hline 1 & 2 & 3 & 4 & 5 & 6 & 7 \\
\hline Analyte & $\begin{array}{c}\text { SB8 WAPS } \\
\text { (\%RSD*) } \\
\text { Mol/L super. } \\
\text { Wt'd Dil. Slurry }\end{array}$ & $\begin{array}{c}\text { SB8 WAPS } \\
\text { (\%RSD*) } \\
\text { Mol/L super. } \\
\text { Wt'd Dil. Super. }\end{array}$ & $\begin{array}{c}\text { SB8 WAPS } \\
\text { (\%RSD*) } \\
\text { mg/kg slurry } \\
\text { Wt'd Dil. Slurry }\end{array}$ & $\begin{array}{c}\text { SB8 WAPS } \\
\text { (\%RSD*) } \\
\text { mg/kg slurry } \\
\text { Wt'd Dil. Super. }\end{array}$ & Method & $\begin{array}{c}\text { SRAT } \\
\text { Receipt for } \\
\text { Batch } 676 \\
\text { mg/kg slurry }\end{array}$ \\
\hline $\mathrm{NO}_{3}^{-}$ & $0.133(0.3)[4]$ & $0.140(0.2)[4]$ & $6910(0.3)[4]$ & $7250(0.2)[4]$ & IC & 11900 \\
\hline $\mathrm{NO}_{2}^{-}$ & $0.295(1.7)[4]$ & $0.312(0.6)[4]$ & $11300(1.7)[4]$ & $12000(0.6)[4]$ & IC & 9370 \\
\hline $\mathrm{SO}_{4}{ }^{2-}$ & $0.0157(0.6)[4]$ & $0.0150(1.4)[4]$ & $1260(0.6)[4]$ & $1200(1.4)[4]$ & IC & 1420 \\
\hline $\mathrm{PO}_{4}^{3-}$ & $<0.0012$ & $<0.0011$ & $<96$ & $<87$ & IC & NA \\
\hline $\mathrm{Br}^{-}$ & $<0.014$ & $<0.013$ & $<960$ & $<880$ & IC & NA \\
\hline $\mathrm{Cl}^{-}$ & $<0.0032$ & $<0.0030$ & $<96$ & $<87$ & IC & NA \\
\hline $\mathrm{CHO}_{2}^{-}$ & $<0.0025$ & $<0.0023$ & $<96$ & $<87$ & IC & 6480 \\
\hline $\mathrm{C}_{2} \mathrm{O}_{4}^{2-}$ & $0.0223(0.4)[4]$ & $0.0216(0.7)[4]$ & $1640(0.4)[4]$ & $1590(0.7)[4]$ & IC & 3000 \\
\hline $\mathrm{F}^{-}$ & $<0.0060$ & $<0.0055$ & $<96$ & $<87$ & IC & NA \\
\hline $\mathrm{Al}$ & NA & $0.0548(0.5)[4]$ & NA & $1240(0.5)[4]$ & ICP-AES & NA \\
\hline $\mathrm{B}$ & NA & $0.000532(0.9)[4]$ & NA & $4.80(0.9)[4]$ & ICP-AES & NA \\
\hline $\mathrm{Ca}$ & NA & $0.000202(0.7)[4]$ & NA & $6.75(0.7)[4]$ & ICP-AES & NA \\
\hline $\mathrm{Cr}$ & NA & $0.000700(0.2)[4]$ & NA & $30.4(0.2)[4]$ & ICP-AES & NA \\
\hline $\mathrm{Fe}$ & NA & $0.0000334(48)[4]$ & NA & $1.56(48)[4]$ & ICP-AES & NA \\
\hline $\mathrm{K}$ & NA & $0.00254(2.9)[4]$ & NA & 83.0 (2.9) [4] & ICP-AES & NA \\
\hline Mo & NA & $0.0000976(2.9)[4]$ & NA & $7.83(2.9)[4]$ & ICP-AES & NA \\
\hline $\mathrm{Na}$ & NA & $1.04(0.4)[4]$ & NA & $19900(0.4)[4]$ & ICP-AES & NA \\
\hline $\mathrm{S}$ & NA & $0.0189(0.9)[4]$ & NA & $508(0.9)[4]$ & ICP-AES & NA \\
\hline $\mathrm{Sr}$ & NA & $0.000000445(1.2)[4]$ & NA & $0.0326(1.2)[4]$ & ICP-AES & NA \\
\hline
\end{tabular}

$\mathrm{NA} \equiv$ not measured

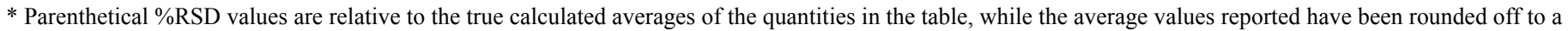
reasonable number of significant figures.

A comparison of anion data, shown in Table 3-2, for this sample and the DWPF SRAT Receipt Batch \#676 is difficult due to a number of factors. The DWPF SRAT receipt nitrite ion concentration would be expected to be reduced relative to the incoming sludge since the heel in the SRAT is reduced in nitrite ion. Similarly, the SRAT formate and nitrate ion concentrations would be expected to be elevated relative to the sludge since the heel in the SRAT is greatly increased in these anions. The nitrite to nitrate ratio observed is considerably different, but is likely due to the large residual heel in the SRAT vessel, the addition of PRFT material, and the concentration of DWPF SRAT receipt material prior to sampling. This pre-concentration of the SRAT receipt material, prior to sampling and analysis, makes a comparison of anion levels very difficult for this sludge batch. Some past sludge batches have been higher in incoming insoluble solids and did not require this pre-concentration boil prior to routine SRAT processing.

The conversion of the total supernate sulfur value, as shown in Table 3-2, from molar to wt.\% of total solids, yields 0.295 wt.\% ( $\pm 0.9 \%$ RSD) $\mathrm{S}$ for the Tank 40 - SB8 WAPS sample. Comparing this value 
with the total slurry sulfur value in Table $3-5$ ( 0.344 wt. $\% \pm 0.6 \%$ RSD) indicates that $\sim 86 \%$ of the sulfur in the WAPS sample is soluble. For SB3 ${ }^{18}, \mathrm{SB}^{20}, \mathrm{SB}^{21}$ and $\mathrm{SB} 7 \mathrm{~b}^{15}, 95 \%, 93 \%, 91 \%$, and $82 \%$ of the sulfur was soluble, respectively, while the SB5 ${ }^{22}$ WAPS sample had only $50 \%$ of the sulfur present in the supernate phase. Since the total sulfur content does not exceed any glass limits for anticipated waste loadings, there should not be any negative consequences to the speciation of the sulfur in SB8. When the SB8 WAPS supernate sulfur value by ICP-AES (Table 3-2 ) is put on a slurry sulfate basis, the result is $1520 \mathrm{mg}$ sulfate/kg slurry. This compares reasonably well with the DWPF sulfate analysis for Batch \#676 of $1420 \mathrm{mg}$ sulfate/kg slurry considering the latter measurement would not include the soluble, non-sulfate sulfur contribution. The values for Batch \#675 and \#677 were 1550 and $1570 \mathrm{mg}$ sulfate $/ \mathrm{kg}$ slurry, respectively, so there is some variability in the DWPF values batch to batch.

Table 3-3 provides the TIC and TOC measured for the SB8 WAPS sample along with the total carbon (TC) value which is reported as the sum of the TIC and TOC values. The first column of values resulted from a weighted dilution of the slurry into water, while the second column of values resulted from a weighted dilution of supernate into water. Note, however, that both sets of results are reported on a slurry basis. The slurry value of TIC is needed for current SRAT processing acid calculations while the supernate TIC value is needed for developmental work on a revised acid calculation, hence both dilution methods were undertaken. The data does support earlier observations that there is an undissolved slurry TIC component that is not measured if only the supernate TIC is measured. It does not demonstrate, however, that the current slurry TIC measurement actually succeeds in dissolving the entire insoluble TIC; hence the $347 \mathrm{mg} / \mathrm{kg}$ insoluble TIC observed is a lower bound on the actual insoluble TIC value. The slurry TIC value measured for SRAT Batch \#676 is $20 \%$ lower than the slurry value determined in SRNL, but no TOC or TC values are available for comparison.

Table 3-3. Carbon Analysis for Tank 40 SB8 WAPS Samples and DWPF SRAT Receipt Batch 676 [Number of Samples Included in Average] (mg C/kg slurry)

\begin{tabular}{|c|c|c|c|}
\hline Analyte & $\begin{array}{c}\text { Slurry Wt'd Dilution } \\
\text { Tank 40 - WAPS } \\
\text { (\%RSD*) }\end{array}$ & $\begin{array}{c}\text { Supernate Wt'd Dilution } \\
\text { Tank 40 - WAPS } \\
\text { (\%RSD*) }\end{array}$ & $\begin{array}{c}\text { SRAT } \\
\text { Receipt for } \\
\text { Batch } 676^{\mathrm{a}}\end{array}$ \\
\hline $\begin{array}{c}\text { Total Inorganic } \\
\text { Carbon }\end{array}$ & $1180(3.9)[4]$ & $833(2.0)$ [4] & 941 \\
\hline $\begin{array}{c}\text { Total Organic } \\
\text { Carbon }\end{array}$ & 448 (4.3) [4] & $527(4.1)[4]$ & NA \\
\hline Total Carbon & $1630(1.5)[4]$ & $1360(1.0)[4]$ & NA \\
\hline
\end{tabular}

Table 3-4 provides the base measurements made on the SB8 WAPS sample. Total base represents the value determined from an inflection endpoint titration to $\mathrm{pH}$. Free $\mathrm{OH}^{-}$represents the value determined after precipitation of carbonate with $\mathrm{BaCl}_{2}$ and titration to the first inflection endpoint between $\mathrm{pH} 11$ and 8 . Further titration of this treated sample to $\mathrm{pH} 7$ yields the value for 'other base'. 
Table 3-4. Base Analysis for Tank 40 SB8 WAPS Samples and DWPF SRAT Receipt Batch 676 [Number of Samples Included in Average] (mol/kg slurry)

\begin{tabular}{|c|c|c|c|}
\hline Analyte & $\begin{array}{c}\text { Slurry Wt'd Dilution } \\
\text { Tank 40 - WAPS } \\
\text { (\%RSD) }\end{array}$ & $\begin{array}{c}\text { Supernate Wt'd Dilution } \\
\text { Tank 40 - WAPS } \\
\text { (\%RSD) }\end{array}$ & $\begin{array}{c}\text { SRAT } \\
\text { Receipt for } \\
{\text { Batch } 676^{\mathrm{a}}}\end{array}$ \\
\hline Total Base & $0.388(3.3)[4]$ & $0.346(2.5)[4]$ & 0.370 \\
\hline Free $\mathrm{OH}^{-}$ & $0.194(3.4)[4]$ & $0.190(1.5)[4]$ & NA \\
\hline Other Base & $0.185(5.9)[4]$ & $<0.098$ & NA \\
\hline
\end{tabular}

The difference between the total base value when free $\mathrm{OH}^{-}$and 'other base' are removed should correspond to the carbonate base equivalents determined via titration. This value, 0.156 moles base $/ \mathrm{kg}$ slurry derived from the supernate dilutions, should correspond to the TIC base equivalents for carbonate determined from the data in Table 3-3. The value of TIC for the slurry weighted dilution gives 0.20 moles base/kg slurry, while the TIC value from the supernate weighted dilution gives 0.14 moles base $/ \mathrm{kg}$ slurry. The supernate determined value would be expected to be lower than the slurry value if there are undissolved carbonates in the solids that are dissolved when the slurry is diluted into water. The carbonate base value (determined from the data in Table 3-4) that was derived from a weighted dilution of slurry is low even if the 'other base' value is assumed to be zero. In other words, the carbonate base value derived from a weighted dilution of slurry is effectively zero, which implies that one or both of the reported free $\mathrm{OH}$ - or the 'other base' values is too high, i.e. a sum of the two exceeds the total base value without consideration of the contribution from carbonate species.

The elemental concentrations determined from ICP-AES, ICP-MS, AA, and CV-AA analyses are presented in Table 3-5. For the Tank 40 - WAPS sample, results from both digestions have been combined where appropriate. When both detection limits and actual values are measured for replicates, only the actual value(s) are included in the average shown in the table. Due to the use of $\mathrm{Zr}$ crucibles and $\mathrm{NaOH} / \mathrm{Na}_{2} \mathrm{O}_{2}$ in the alkali fusions, $\mathrm{Zr}$ and $\mathrm{Na}$ values, as well as other alkali metals, were determined from the aqua regia digestion. In the case of $\mathrm{B}, \mathrm{Be}, \mathrm{Sb}$, and $\mathrm{V}$, both preparations yielded values below the detection limits; hence the lowest detection limit value was selected. Alkali fusion data was used to report values for $\mathrm{Al}$ and $\mathrm{Si}$ for the Tank 40 - WAPS sample since the aqua regia preparation fails to dissolve all forms of these elements. The aqua regia data was used to report $\mathrm{Cr}, \mathrm{Sr}$, and $\mathrm{Zn}$ since the ARG-1 glass value for $\mathrm{Cr}, \mathrm{Sr}$, and $\mathrm{Zn}$ by alkali fusion were biased high. ICP-MS analysis of the aqua regia digestion was also used to determine the concentrations of $\mathrm{Cd}, \mathrm{Ce}, \mathrm{Gd}, \mathrm{La}, \mathrm{Nd}, \mathrm{Pb}, \mathrm{Th}$, and $\mathrm{U}$. The various isotopes used from the ICP-MS analysis are indicated in the footnotes to Table 3-5. In the case of $\mathrm{Ce}$ and $\mathrm{Nd}$ the distribution of isotopes was not according to their natural abundances but rather the result of fission product yields from U-235. Hence the sum of the respective isotopic masses was used to determine the reported concentrations for $\mathrm{Ce}, \mathrm{Nd}$, and $\mathrm{U}$. The $\mathrm{U}$ value reported here from ICP-MS compares to a value determined by ICP-AES of 3.73 wt.\% of total solids. For $\mathrm{Cd}, \mathrm{Gd}$, and $\mathrm{Pb}$, the reported value was determined from all measured values calculated using the various isotopes' natural abundance. In the case of La-139 and Th-232, a single isotope has essentially $100 \%$ natural abundance and was used to calculate the values given in the table. 
Where there are also ICP-AES results for elements reported in Table 3-5 based on their ICP-MS data, these have been included in Table A-1 in Appendix A. There is generally good agreement between the ICP-MS and ICP-AES results. SRNL is still developing a protocol to propagate the uncertainties for merging the data from the two instruments into a single value for future reports.

Table 3-5. Elemental Concentrations* in Tank 40 SB8 WAPS Samples in

Wt. \% of Total Dried Solids (\%RSD**)

[Number of Samples Included in Average]

\begin{tabular}{|c|c|c|c|}
\hline Element & Tank 40 - WAPS & Element & Tank 40 - WAPS \\
\hline $\mathrm{Al}$ & $6.98(1.1)[4]$ & Mo & $0.0106(3.1)[4]$ \\
\hline $\mathrm{As}^{\wedge \wedge}$ & $<0.00053$ & $\mathrm{Na}$ & $14.5(0.3)[4]$ \\
\hline $\mathrm{B}$ & $<0.021$ & $\mathrm{Nd}^{\$}$ & $0.179(0.6)[4]$ \\
\hline $\mathrm{Ba}$ & $0.0851(1.4)[8]$ & $\mathrm{Ni}$ & $1.64(0.6)[8]$ \\
\hline $\mathrm{Be}$ & $<0.00038$ & $\mathrm{P}$ & $0.140(9.4)[4]$ \\
\hline $\mathrm{Ca}$ & $0.968(0.3)[4]$ & $\mathrm{Pb}^{\ddagger}$ & $0.0339(4.4)[4]$ \\
\hline $\mathrm{Cd}^{*}$ & $0.0162(11)[4]$ & $\mathrm{S}$ & $0.344(0.6)[4]$ \\
\hline $\mathrm{Ce}^{\mathrm{t}}$ & $0.212(0.2)[4]$ & $\mathrm{Se}^{\wedge \wedge}$ & $<0.0011$ \\
\hline $\mathrm{Co}$ & $0.0108(12)[8]$ & $\mathrm{Sb}$ & $<0.011$ \\
\hline $\mathrm{Cr}$ & $0.0729(5.5)[4]$ & $\mathrm{Si}$ & $1.10(7.8)[4]$ \\
\hline $\mathrm{Cu}$ & $0.0699(0.3)[4]$ & Sn & $0.00495(11)[3]$ \\
\hline $\mathrm{Fe}$ & $16.9(1.2)[8]$ & $\mathrm{Sr}$ & $0.0321(0.3)[4]$ \\
\hline $\mathrm{Gd}^{\ddagger}$ & $0.0816(3.9)[4]$ & $\mathrm{Th}^{*}$ & $0.816(1.3)[4]$ \\
\hline $\mathrm{Hg}^{\wedge}$ & $1.86(2.6)[4]$ & $\mathrm{Ti}$ & $0.0140(4.0)[7]$ \\
\hline $\mathrm{K}$ & $0.106(10)[4]$ & $\mathrm{U}^{+*}$ & $3.74(0.3)[4]$ \\
\hline $\mathrm{La}^{\ddagger}$ & $0.0518(0.7)[4]$ & $\mathrm{V}$ & $<0.00027$ \\
\hline $\mathrm{Li}$ & $0.0142(7)[4]$ & $\mathrm{Zn}$ & $0.0267(1.0)[4]$ \\
\hline $\mathrm{Mg}$ & $0.229(3.5)[8]$ & $\mathrm{Zr}^{+\mathrm{H}}$ & $0.0658(24)[4]$ \\
\hline $\mathrm{Mn}$ & $5.29(1.1)[8]$ & & \\
\hline \multicolumn{4}{|c|}{ 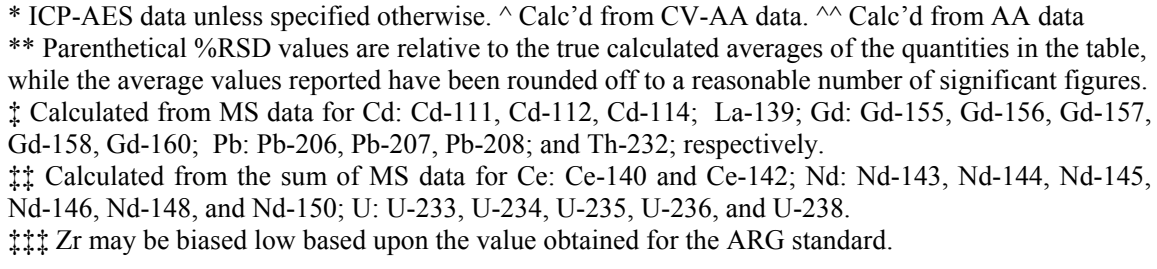 } \\
\hline
\end{tabular}

A comparison of the major elemental ratios of the insoluble solids using data from Table 3-5 is given in Table 3-6. SRAT Receipt Batch \#676 data is from DWPF and was used to calculate the ratios of Fe to $\mathrm{Al}, \mathrm{Ca}, \mathrm{Mn}$, and $\mathrm{U}$. These ratios should remain constant through batch processing unless an addition of material containing one or more elements of interest is made. 
Generally, the elemental ratios observed for SB4 and SB5 are very similar for these major elements. SB6 was the most unique of the last six sludge batches. SB7 ${ }^{19}$ and SB7b are similar in the $\mathrm{Ca}$ and $\mathrm{U}$ ratios to $\mathrm{Fe}$, but dissimilar in the ratios of $\mathrm{Al}$ and $\mathrm{Mn}$. SB8 has the lowest $\mathrm{Al} / \mathrm{Fe}$ and $\mathrm{U} / \mathrm{Fe}$ ratios observed for the last six sludge batches and a $\mathrm{Mn} / \mathrm{Fe}$ ratio last observed for SB6. The agreement between the SB8 WAPS sample and the DWPF Batch \#676 data is excellent. The $\mathrm{Ca} / \mathrm{Fe}$ and $\mathrm{Mn} / \mathrm{Fe}$ ratios are in reasonable agreement with the DWPF data from either their Cold Chem (CC) or Alkali Fusion (AF) digestion methods. A lower $\mathrm{Al} / \mathrm{Fe}$ ratio (0.37) is obtained from the DWPF CC method due to the low bias in this method from incomplete dissolution of Al. A lower U/Fe ratio (0.20) is obtained from the DWPF PF method, and this low bias was also true for DWPF Batches \#675 and \#677, indicating that $\mathrm{U}$ is probably best determined from the $\mathrm{CC}$ method.

Table 3-6. Comparison of Elemental Ratios for Major Insoluble Elements in the Tank 40 SB4, SB5, SB6, SB7a, SB7b, and SB8 Samples with DWPF Batch 676 SRAT Receipt Data

\begin{tabular}{|c|c|c|c|c|c|c|c|c|c|}
\hline $\begin{array}{c}\text { Element } \\
\text { Ratio }\end{array}$ & $\begin{array}{c}\text { SB4 } \\
\text { WAPS }^{20}\end{array}$ & $\begin{array}{c}\text { SB5 } \\
\text { WAPS }^{22}\end{array}$ & $\begin{array}{c}\text { SB6 } \\
\text { WAPS }^{21}\end{array}$ & $\begin{array}{c}\text { SB7a } \\
\text { WAPS }^{19}\end{array}$ & $\begin{array}{c}\text { SB7b } \\
\text { WAPS }^{15}\end{array}$ & $\begin{array}{c}\text { SB8 } \\
\text { WAPS }\end{array}$ & $\begin{array}{c}\text { DWPF SRAT } \\
\text { Receipt } \\
\text { Batch } 676\end{array}$ & $\begin{array}{c}\text { \% Difference } \\
\text { SB8 WAPS - } \\
\text { Batch } 676\end{array}$ & $\begin{array}{c}\text { DWPF } \\
\text { Method* }\end{array}$ \\
\hline $\mathrm{Al} / \mathrm{Fe}$ & 0.67 & 0.60 & 0.76 & 0.71 & 0.66 & 0.41 & 0.40 & -3 & $\mathrm{AF}$ \\
\hline $\mathrm{Ca} / \mathrm{Fe}$ & 0.099 & 0.092 & 0.062 & 0.051 & 0.050 & 0.057 & 0.057 & 0 & $\mathrm{CC}$ \\
\hline $\mathrm{Mn} / \mathrm{Fe}$ & 0.22 & 0.23 & 0.31 & 0.28 & 0.22 & 0.31 & 0.33 & 5 & $\mathrm{AF}$ \\
\hline $\mathrm{U} / \mathrm{Fe}$ & 0.37 & 0.33 & 0.26 & 0.34 & 0.34 & 0.22 & 0.22 & -2 & $\mathrm{CC}$ \\
\hline $\begin{array}{l}{ }^{0} \text { Reboul, S. } \\
\text { Bannochie, } \\
{ }^{1} \text { Bannochie, } \\
2 \text { Bannochie } \\
\text { River Site, } \\
{ }^{5} \text { Bannochie }\end{array}$ & $\begin{array}{l}\text { chemical, A } \\
\text {., Click, D. R. } \\
\text { C. J., Tank } 401 \\
\text { C. J., Tank } 40 \\
\text { C. J., Click, D } \\
\text { Aiken, SC } 2980\end{array}$ & $\begin{array}{l}\text { al SB4 Chen } \\
\text { al SB6 Chen } \\
\text { R., Tank } 40 \\
\text { (2010). }\end{array}$ & $\begin{array}{l}\text { ion } \\
\text { ents in SB7a } \\
\text { cal Characte } \\
\text { cal Characte } \\
\text { Final SB5 C }\end{array}$ & $\begin{array}{l}\text { ation Results } \\
\text { ation Results } \\
\text { mical Charac }\end{array}$ & , WSRC-ST & $10-004$ & $\begin{array}{l}\text { 1-00133, Savannah } \\
\text { Savannah River Sit } \\
\text { avannah River Site } \\
\text { Np Addition, SRN }\end{array}$ & $\begin{array}{l}\text { er Site, Aiken, S } \\
\text { iken, SC } 29808 \text { ( } \\
\text { ken, SC } 29808 \text { (2 } \\
\text { TI-2009-00060, }\end{array}$ & $\begin{array}{l}\text { 9808 (2011). } \\
\text { 8). } \\
\text { ). }\end{array}$ \\
\hline
\end{tabular}

Table 3-7 and Table 3-8 provide the replicate measurements for $\mathrm{Fe}$ (whose average was reported in Table 3-5) and the fissile isotopes, U-233, U-235, Pu-239, and Pu-241 for the SB8 WAPS sample, respectively. This data along with the replicate solids and density measurements given in Table 3-9 are reported to allow for the verification of canister fissile limits in DWPF.

Table 3-7. Replicate Concentrations of Iron for the Tank 40 SB8 WAPS Sample in Wt.\% of Total Dried Solids

\begin{tabular}{cccccccc}
\hline Element & Repl. 1 & Repl. 2 & Repl. 3 & Repl. 4 & Average & Instrument & $\begin{array}{c}\text { Prep } \\
\text { Method }\end{array}$ \\
\hline $\mathrm{Fe}$ & 16.8 & 16.7 & 16.8 & 16.8 & 16.8 & ICP-AES & AR \\
$\mathrm{Fe}$ & 16.9 & 17.1 & 17.3 & 16.9 & 17.1 & ICP-AES & PF \\
$\mathrm{Fe}$ & - & - & - & - & 16.9 & ICP-AES & AR/PF \\
\hline
\end{tabular}

$\mathrm{AR} \equiv$ aqua regia digestion, $\mathrm{PF} \equiv$ peroxide fusion digestion 
SRNL-STI-2013-00504

Revision 0

Table 3-8. Replicate Activities of Fissile Radionuclides for the Tank 40 SB8 WAPS Sample in $\mu \mathrm{Ci} / \mathrm{g}$ of Total Dried Solids*

\begin{tabular}{ccccccc}
\hline Radionuclide & Repl. 1 & Repl. 2 & Repl. 3 & Repl. 4 & Reported & \%RSD** \\
& & & & & & \\
\hline U-233 & $6.19 \mathrm{E}-02$ & $7.81 \mathrm{E}-02$ & $6.31 \mathrm{E}-02$ & $5.78 \mathrm{E}-02$ & $6.52 \mathrm{E}-02$ & 14 \\
$\mathrm{U}-235$ & $5.13 \mathrm{E}-04$ & $5.41 \mathrm{E}-04$ & $5.18 \mathrm{E}-04$ & $5.08 \mathrm{E}-04$ & $5.20 \mathrm{E}-04$ & 2.8 \\
$\mathrm{Pu}-239$ & $8.11 \mathrm{E}+00$ & $7.73 \mathrm{E}+00$ & $7.46 \mathrm{E}+00$ & $7.82 \mathrm{E}+00$ & $7.78 \mathrm{E}+00$ & 3.4 \\
$\mathrm{Pu}-241^{\ddagger}$ & $<4.2 \mathrm{E}+01$ & $4.35 \mathrm{E}+01$ & $4.31 \mathrm{E}+01$ & $4.31 \mathrm{E}+01$ & $4.32 \mathrm{E}+01$ & 0.5 \\
\hline
\end{tabular}

* ICP-MS data unless specified otherwise

${ }^{\ddagger} \mathrm{Pu}-238 /-241$ method. See Ref. 11 for description.

**Values in the \%RSD column are relative to the true calculated averages of the quantities in the table, while the average values reported have been rounded off to a reasonable number of significant figures.

Unlike SB6 ${ }^{21}$ which was enriched to 0.756 wt. $\%$ U-235, SB8 shows 0.643 wt.\% enrichment, i.e. contains depleted U. Normal U enrichment is $0.711 \mathrm{wt} . \%$.

Table 3-9. Replicate Weight Percent Solids and Densities for Tank 40 SB8 WAPS Sample

\begin{tabular}{cccccccccc}
\hline $\begin{array}{c}\text { Species } \\
\text { (Wt.\% Solids } \\
\text { are Slurry } \\
\text { Basis) }\end{array}$ & Repl. 1 & Repl. 2 & Repl. 3 & Repl. 4 & Repl. 5 & Repl. 6 & Repl. 7 & Repl. 8 & Average \\
\hline $\begin{array}{c}\text { Wt.\% Total } \\
\text { Solids }\end{array}$ & 17.09 & 17.04 & 17.03 & 17.10 & 17.30 & 17.40 & 17.44 & 17.25 & 17.21 \\
$\begin{array}{c}\text { Wt.\% Calcined } \\
\quad \begin{array}{l}\text { Solids } \\
\text { Slurry Density, } \\
\text { g/mL }\end{array}\end{array}$ & 13.24 & 13.01 & 13.19 & 13.08 & NA & NA & NA & NA & 13.13 \\
$\begin{array}{c}\text { Supernate } \\
\text { Density, g/mL }\end{array}$ & 1.060 & 1.058 & 1.062 & 1.063 & NA & NA & NA & NA & 1.06 \\
\hline NA $\equiv$ not applicable & & 1.162 & 1.154 & 1.142 & NA & NA & NA & NA & 1.16 \\
\hline
\end{tabular}

The fission product noble metal and silver concentrations are given in Table 3-10 and Figure 3-1. The values were calculated from ICP-MS data using an Excel spreadsheet. This spreadsheet uses the fission yield for each isotope to account for the mass contribution from isotopes in the tank that could not be measured because isotopes of natural $\mathrm{Cd}$ interfere at this mass. An example of this is the measurement at mass 110, which is comprised of Pd-110 and Cd-110. The uncertainties were analyzed using statistical techniques appropriate for replicate measurements of non-highly correlated data. For comparison purposes, the SB4 WAPS ${ }^{20}$, SB5 WAPS ${ }^{22}$, SB6 WAPS ${ }^{21}$, SB7a WAPS ${ }^{15}$ and SB7b WAPS ${ }^{15}$ samples are also given in this table. The results indicate there has been a general leveling off in fission product noble metal and silver concentrations over the previous five sludge batches. With SB8, the [Ru] has fallen considerably, back below SB5 levels. The silver concentration appears to have peaked in $\mathrm{SB} 7 \mathrm{a}$, [Pd] peaked in SB6, and [Ru] peaked in SB7b, while [Rh] had been fairly constant across SB6, SB7a, and SB7b, but has now decreased like that of Ru to below SB5 levels. 
SRNL-STI-2013-00504

Revision 0

Table 3-10. Noble Metal Fission Product and Silver Concentrations in Tank 40 SB4, SB5, SB6, SB7a, SB7b, and SB8 WAPS Samples in Wt. \% of Total Solids (\%RSD)

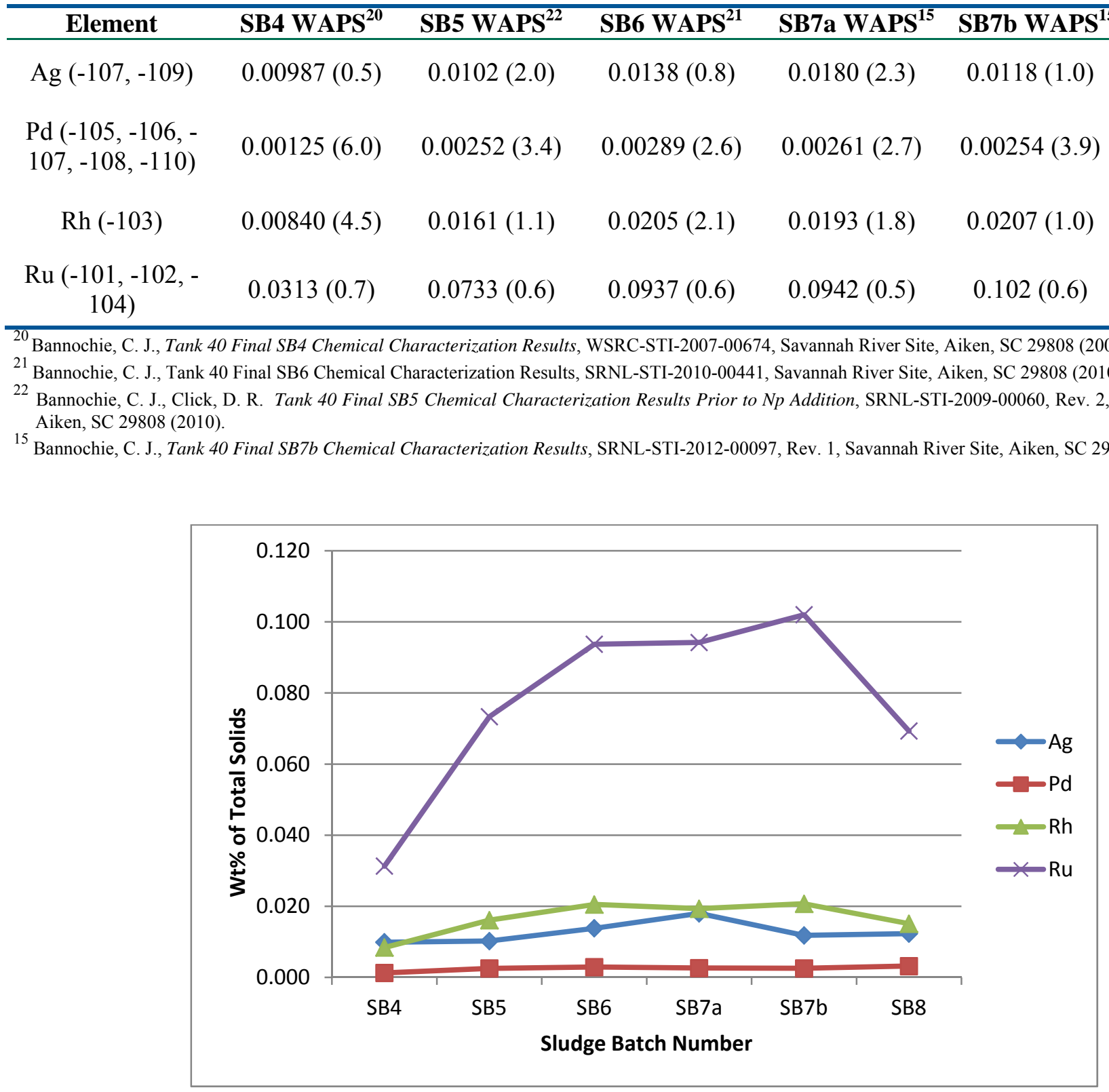

Figure 3-1. Noble Metal Fission Product and Silver Concentrations (Wt. \% of Total Solids) in Tank 40 WAPS Samples for SB4 through SB8

A comparison of the fission yield mass ratios for $\mathrm{Ru}: \mathrm{Rh}, \mathrm{Ru}: \mathrm{Pd}$, and $\mathrm{Ru}: \mathrm{Ag}$ with those measured for the SB8 WAPS sample is provided in Table 3-11. The SB4, SB5, SB6, SB7a, and SB7b WAPS sample results are also provided for comparison. The mass ratios are based upon $\mathrm{Ru}$ due to its relatively high concentration in the sludge as compared with the other noble metals. The $\mathrm{Ru}: \mathrm{Rh}$ ratio agrees reasonably well, while the Ru:Ag ratios differ significantly from the fission yield ratios. This lack of agreement for the $\mathrm{Ag}$ ratios is not unexpected. The majority of the $\mathrm{Ag}$ is natural $\mathrm{Ag}$ originating from $\mathrm{Ag}$ saddles used 
in the dissolvers to scavenge radioactive iodine, while the noble metals are fission products of U-235. Consequently, the relative concentration of $\mathrm{Ag}$ is not expected to be in proportion to the fission yields of its two isotopes. The Ru:Pd ratios agree reasonably well amongst the samples but not with that predicted by the fission yield. A possible explanation for this is that a portion of the $\mathrm{Pd}$ is soluble and hence has fractioned off into the salt waste, thus increasing the ratio of $\mathrm{Ru}$ to $\mathrm{Pd}$ in the sludge waste. This fractionation appeared to be increasing over the past five sludge batches, but has dropped significantly for SB8.

Table 3-11. Fission Yield Ratios and Measured Noble Metal Ratios in SB4, SB5, SB6, SB7a, SB7b, and SB8 WAPS Samples

\begin{tabular}{|c|c|c|c|c|c|c|c|}
\hline Ratio & $\begin{array}{c}\text { Fission } \\
\text { Yield }\end{array}$ & $\begin{array}{c}\text { SB4 } \\
\text { WAPS }^{20}\end{array}$ & $\begin{array}{c}\text { SB5 } \\
\text { WAPS }^{22}\end{array}$ & $\begin{array}{c}\text { SB6 } \\
\text { WAPS }^{21}\end{array}$ & $\begin{array}{c}\text { SB7a } \\
\text { WAPS }^{15}\end{array}$ & $\begin{array}{c}\text { SB7b } \\
\text { WAPS }^{15}\end{array}$ & $\begin{array}{c}\text { SB8 } \\
\text { WAPS }\end{array}$ \\
\hline $\mathrm{Ru}: \mathrm{Rh}$ & 3.7 & 3.7 & 4.6 & 4.6 & 4.9 & 4.9 & 4.6 \\
\hline $\mathrm{Ru}: \mathrm{Pd}$ & 6.9 & 25 & 29 & 32 & 36 & 40 & 22 \\
\hline $\mathrm{Ru}: \mathrm{Ag}$ & 342 & 3.2 & 7.2 & 6.8 & 5.2 & 8.6 & 5.6 \\
\hline \multicolumn{8}{|c|}{$\begin{array}{l}\text { Bannochie, C. J., Tank } 40 \text { Final SB4 Chemical Characterization Results, WSRC-STI-2007-00674, Savannah River Site, Aiken, SC } \\
29808 \text { (2008). }\end{array}$} \\
\hline \multicolumn{8}{|c|}{$\begin{array}{l}21 \text { Bannochie, C. J., Tank } 40 \text { Final SB6 Chemical Characterization Results, SRNL-STI-2010-00441, Savannah River Site, Aiken, SC } \\
29808 \text { (2010). } \\
22 \text { Bannochie, C. J., Click, D. R., Tank } 40 \text { Final SB5 Chemical Characterization Results Prior to Np Addition, SRNL-STI-2009-00060, } \\
15 \text { Rev. 2, Savannah River Site, Aiken, SC } 29808 \text { (2010). }\end{array}$} \\
\hline & C. J., Tank 40 & & & & & & \\
\hline
\end{tabular}

\subsection{Conclusions}

- The ratios of the major elements for the SB8 WAPS sample are different from those measured for the SB7b WAPS sample. There is less $\mathrm{Al}$ and $\mathrm{U}$, and more Mn relative to Fe than the previous sludge batch.

- The elemental composition of this sample and the analyses conducted here are reasonable and consistent with DWPF batch data measurements in light of DWPF pre-sample concentration, SRAT product heel contributions, and PRFT additions to the DWPF SRAT receipt sample. The element ratios for $\mathrm{Al} / \mathrm{Fe}, \mathrm{Ca} / \mathrm{Fe}, \mathrm{Mn} / \mathrm{Fe}$, and $\mathrm{U} / \mathrm{Fe}$ agree within $5 \%$ between this work and the DWPF SRAT receipt analyses.

- Sulfur in the SB8 WAPS sample is $86 \%$ soluble, slightly less than results reported for SB3, SB4, and SB6 samples but unlike the 50\% insoluble sulfur observed in the SB5 WAPS sample. In addition, $21 \%$ of the soluble sulfur is not present as sulfate in SB8.

- The average activities of the fissile isotopes of interest in the SB8 WAPS sample are (in $\mu \mathrm{Ci} / \mathrm{g}$ of total dried solids): 6.52E-02 U-233, 5.20E-04 U-235, 7.78E+00 Pu-239, and 4.32E+01 Pu-241. The full radionuclide composition will be reported in a future document.

- The fission product noble metal and Ag concentrations appear to have largely peaked in previous DWPF sludge batches. The concentration of Ru has decreased significantly in SB8. 


\subsection{References}

1. Office of Environmental Restoration and Waste Management, Waste Acceptance Product Specifications for Vitrified High-Level Waste Forms, US DOE Document DOE/EM-0093, Rev. 2, (12/96).

2. Samadi, A. Sludge Batch 8 Qualification Studies, HLW-DWPF-TTR-2012-0009, Rev. 2, Savannah River Site, Aiken, SC 29808 (2013).

3. Pareizs, J. M., Click, D. R. Task Technical and Quality Assurance Plan for Sludge Batch 8 Qualification in the Shielded Cells, SRNL-RP-2012-00253, Rev. 0, Savannah River Site, Aiken, SC 29808 (2012).

4. Pareizs, J. M., Click, D. R. Analytical Study Plan for Qualification of Sludge Batch 8 in the Shielded Cells:, SRNL-RP-2012-00561, Rev. 0, Savannah River Site, Aiken, SC 29808 (2012).

5. Lambert, D. P., Martino, C. J., Bannochie, C. J. Task Technical and Quality Assurance Plan for DWPF Chemical Process Cell Actual Waste Processability Testing, SRNL-RP-2013-00340, Rev. 0, Savannah River Site, Aiken, SC 29808 (2013).

6. McIlmoyle, D. W., Gillam, J. M. Projected Blend Composition and Summary of Sludge Batch 8 After Tank 51 to 40 Transfer, X-ESR-H-00521, Rev. 1, Savannah River Site, Aiken, SC 29808 (2013).

7. Bannochie, C. J., Martino, C. J. Tank 40 DWPF Sludge Batch 8: Initial Comparison of 3-L Samples, SRNL-L3100-2013-00140, Savannah River Site, Aiken, SC 29808 (2013).

8. Coleman, C. J. Aqua Regia Dissolution of Sludge for Elemental Analysis, Manual L16.1, Procedure ADS-2226, Rev. 9, Savannah River Site, Aiken, SC 29808 (2009).

9. Coleman, C. J. Alkali Fusion Dissolutions of Sludge and Glass for Elemental and Anion Analysis, Manual L16.1, ADS-2502, Rev. 6, Savannah River Site, Aiken, SC 29808 (2008).

10. Smith, G. L. Characterization of Analytical Reference Glass - 1 (ARG-1), PNL-8992, Pacific Northwest (National) Laboratory, Richland, WA (1993).

11. Bannochie, C. J., DiPrete, D. P. Determination of Reportable Radionuclides for DWPF Sludge Batch 6 (Macrobatch 7), SRNL-STI-2011-00189, Savannah River Site, Aiken, SC 29808 (2011).

12. Marek, J. C. Correction Factor for Soluble and Insoluble Solids, SRTC-PTD-92-0040, Savannah River Site, Aiken, SC 29808 (1992).

13. Pareizs, J. M., Weight Percent Solids Determination Using A Furnace or Oven, Manual L29, Procedure ITS-0078, Rev. 1, Savannah River Site, Aiken, SC 29808 (2012).

14. McIlmoyle, D. W., Gillam, J. M. Projected Blend Composition and Summary of Sludge Batch 8 After Tank 51 to 40 Transfer, X-ESR-H-00521, Rev. 1, Savannah River Site, Aiken, SC 29808 (2013). 
15. Bannochie, C. J. Tank 40 Final SB7b Chemical Characterization Results, SRNL-STI-2012-00097, Rev. 1, Savannah River Site, Aiken, SC 29808 (2012).

16. Bannochie, C. J., Click, D. R., and Pareizs, J. M. Sludge Batch 7 Preparation: Tank 4 and 12 Characterization, SRNL-STI-2010-00223, Savannah River Site, Aiken, SC 29808 (2010).

17. Bannochie, C. J., Wiedenman, B. J. Examination of Sulfur Measurements in DWPF Slude Slurry and SRAT Product Materials, SRNL-STI-2012-00561, Savannah River Site, Aiken, SC 29808 (2012).

18. Bannochie, C. J., Fellinger, T. L, and Pareizs, J. M. Tank 40 Final SB3 Chemical Characterization Results, WSRC-TR-2005-00049, Savannah River Site, Aiken, SC 29808 (2005).

19. Reboul, S. H., Click, D. R. Stable Constituents in SB7a Tank 40 WAPS Sample, SRNL-L3100-201100133, Savannah River Site, Aiken, SC 29808 (2011).

20. Bannochie, C. J., Tank 40 Final SB4 Chemical Characterization Results, WSRC-STI-2007-00674, Savannah River Site, Aiken, SC 29808 (2008).

21. Bannochie, C. J., Tank 40 Final SB6 Chemical Characterization Results, SRNL-STI-2010-00441, Savannah River Site, Aiken, SC 29808 (2010).

22. Bannochie, C. J., Click, D. R. Tank 40 Final SB5 Chemical Characterization Results Prior to Np Addition, SRNL-STI-2009-00060, Rev. 2, Savannah River Site, Aiken, SC 29808 (2010). 
Appendix A 
Table A-1. ICP-AES Results for Elements Reported Based on ICP-MS Data in Table 3-5 for Tank 40 SB8 WAPS Samples in Wt.\% of Total Dried Solids (\%RSD**) [Number of Samples Included in Average]

\begin{tabular}{cc}
\hline Element & Tank 40 - WAPS \\
\hline $\mathrm{Cd}$ & $0.0173(10)[8]$ \\
$\mathrm{Ce}$ & $0.218(2.2)[8]$ \\
$\mathrm{Gd}$ & $0.0852(4.4)[8]$ \\
$\mathrm{La}$ & $0.0509(3.0)[8]$ \\
$\mathrm{Pb}$ & $0.0372(1.4)[4]$ \\
$\mathrm{Th}$ & $0.863(1.5)[8]$ \\
$\mathrm{U}$ & $3.73(2.9)[8]$ \\
\hline
\end{tabular}

** Parenthetical \%RSD values are relative to the true calculated averages of the quantities in the table, while the average values reported have been rounded off to a reasonable number of significant figures. 


\section{Distribution:}

S. L. Marra, 773-A

D. R. Click, 999-W

T. B. Brown, 773-A

S. D. Fink, 773-A

C. C. Herman, 999-W

E. N. Hoffman, 999-W

F. M. Pennebaker, 773-42A

W. R. Wilmarth, 773-A

Records Administration (EDWS)

W. A. Drown, Jr., 773-41A

C. M. Jantzen, 773-A

C. L. Crawford, 773-42A

J. M. Pareizs, 773-A

S. H. Reboul, 773-A

T. B. Edwards, 999-W

K. M. Fox, 999-W

F. C. Johnson, 999-W

D. P. Lambert, 999-W

J. D. Newell, 999-W

D. K. Peeler, 999-W

M. E Stone, 999-W

J. R. Zamecnik, 999-W

J. W. Amoroso, 999-W

P. R. Jackson, DOE-SR, 703-46A

J. M. Bricker, 704-27S

T. L. Fellinger, 704-26S

A. Samadi-Dezfouli, 704-27S

R. N. Hinds, 704-S

E. W. Holtzscheiter, 704-15S

J. F. Iaukea, 704-30S

R. T. McNew, 704-27S

E. J. Freed, 704-S

J. W. Ray, 704-S

D. C. Sherburne, 704-S

H. H. Elder, 704-24S

J. M. Gillam, 766-H

B. A. Hamm, 766-H

D. A. McIlmoyle, 766-H

M. T. Keefer, 766-H

H. B. Shah, 766-H

A. R. Shafer, 241-197H

K. H. Subramanian, 249-8H 